Original Article

\title{
SALINITY IN DRINKING WATER AND BLOOD PRESSURE STATUS OF ADOLESCENT SCHOOL CHILDREN IN COASTAL AREA OF BANGLADESH
}

\author{
Irin Hossain ${ }^{1}$, Manzurul Haque Khan ${ }^{2}$
}

\begin{abstract}
Background: High dietary salt intake from food is a major risk factor for raised blood pressure (BP) worldwide. In the context of Bangladesh, information regarding salinity in water and blood pressure especially in the adolescent population is very scarce. This study was conducted to assess the blood pressure status of adolescent school children in coastal area of Bangladesh.
\end{abstract}

Methods: A one-year school based cross-sectional study was carried out among 528 students of class 8-10 at schools of Bajua Union, Dacope Upazilla, saline prone zone of Khulna district. Relevant data were collected by using pre tested semi-structured questionnaire with face to face interview \& checklist. Blood pressure was measured in a controlled environment and Collected water sources were analyzed by DPHE, Water Testing Laboratory. The study was conducted in the schools of Bajua Union, Dacope Upazilla of the saline prone zone of Khulna district in between a one-year time frame.

Results: Among 528 participants most of them were male (353, 66.9\%) with an age of 14 years $(185,35.0 \%)$. Most of them were read in class $8(185,35.0 \%)$. Prevalence of paternal, maternal, paternal grandparents' and maternal grandparents' history of hypertension were found significant. About $72.3 \%$ regularly took extra salt during meal and $43.9 \%$ took salt preserved fish with meal. Mean of systolic blood pressure of respondents were $114.2197 \pm 7.61448$ $\mathrm{mm}$ of $\mathrm{Hg}$. Mean of diastolic blood pressure of respondents were $75.1780 \pm 5.45959 \mathrm{~mm}$ of $\mathrm{Hg}$. Mean of pulse pressure of respondents were $39.0417 \pm 6.56430$. Mean of mean arterial pressure of respondents were $88.1919 \pm 5.44267 \mathrm{~mm}$ of $\mathrm{Hg}$. Sodium concentration of pond were approximately in between $500-600 \mathrm{mg} / 1$, whereas in tube wells approximately in between $700-1100 \mathrm{mg} / 1$.

Conclusion: Drinking water sodium is an important source of daily sodium intake, and therefore a risk factor for increased BP in salinity prone coastal areas. This adds to the cardiovascular health risks associated with food sodium intake in Southeast Asian populations. Low- saline alternative drinking water sources could effectively help to prevent high BP and hypertension-related morbidity and mortality in these coastal populations. New technologies for the supply of such alternative sources, including safeguarding the microbial quality, should be further studied.

JOPSOM 2020; 39(1): 60-66

https://doi.org/10.3329/jopsom.v39i1.51863

Key Words: Drinking water salinity, Blood pressure status, Adolescent school children, Coastal Bangladesh.

1. Assistant Professor Department of Occupational and Environmental Health, NIPSOM, Dhaka

2. Former Professor Department of Occupational and Environmental Health, NIPSOM, Dhaka

\section{Correspondence:}

Irin Hossain
Assistant Professor, Department of Occupational
and Environmental Health, NIPSOM, Dhaka.
e-mail: irin.hossain@gmail.com

Irin Hossain and Environmental Health, NIPSOM, Dhaka. e-mail:irin.hossain@gmail.com

\section{INTRODUCTION}

Salinity means the relative concentration of dissolved salts, usually sodium chloride, in given water ${ }^{1,2,3} \cdot \mathrm{NaCl}$ accounts for almost $65.7 \%$ of the dissolved salts that causes salinity of water ${ }^{1-4}$. WHO experts defined 'salt' as a combination of sodium $(\mathrm{Na})$ Potassium $(\mathrm{K})$, Iron (Fe), Calcium (Ca), Magnesium (Mg), Chloride (Cl) and Sulphate $(\mathrm{SO} 4)^{5-8}$. In 2002, the World Health Organization (WHO) recognized health impacts of consumption of highly saline waters as a priority for investigation under its public health initiatives ${ }^{8,9}$. Salinity intrusion into drinking water and its associated health impact is one such critical issue ${ }^{9-12}$ with increased blood pressure (BP) or hypertension leading way to cardiovascular diseases (CVD) ${ }^{13,14}$. This is of particular concern for a country like Bangladesh where large coastal population drinks 
water from sources with elevated salinity level ${ }^{15}$. Coastal areas of Bangladesh cover $20 \%$ of total land of the country ${ }^{16,17}$. Tidal and estuarine floodplains cover almost $98 \%$ of the coastal area ${ }^{18}$. Small areas $(2 \%)$ with river floodplains and peat basins are found in the northern part of the coastal area ${ }^{19,20}$. Tidal floodplains occur in Satkhira, Khulna, Bagerhat, Pirozpur, Jhalukhati, Barisal, Patuakhali, Chittagong and Cox's Bazar district ${ }^{20,21}$. They cover a total of $18,65,000$ ha or about $65 \%$ of the coastal area ${ }^{22,23}$. Estuarine floodplains occur in Noakhali, Bhola and Patuakhali districts and in the north-western part of Chittagong district ${ }^{24,25}$.

Hypertension (HTN) or high blood pressure, sometimes called arterial hypertension, is a chronic medical condition in which the arterial blood pressure is elevated ${ }^{25,26}$. High dietary salt intake from food is a major risk factor for raised blood pressure (BP) worldwide ${ }^{26-30}$. The prevalence of increased blood pressure is reported in 4 to $15 \%$ children worldwide, with increasing trends during recent decades ${ }^{31}$. In the present study, it was aimed to explore the relationship between salinity in drinking water and blood pressure status in school going adolescents living in coastal part of Bangladesh.

\section{METHODS}

A one-year school based cross-sectional study was carried out among 528 students of class 8-10. For the calculation of sample size mean and standard deviation (SD's) of blood pressure (systolic and diastolic) were used which values were taken from Robert W, T, EdwardJ, C (1981) ${ }^{32}$. Schools of Bajua Union, Dacope Upazilla of the saline prone zone of Khulna district which was established by baseline survey data of national drinking water quality of Bangladesh ${ }^{33,34}$. Data was collected by conducting face to face interview with questionnaire on school children after having their informed consent. The questionnaire was included socio demographic characteristics information, sources of drinking and cooking water, extra salt intake and salted fish intake, family history of blood pressure related information. Blood pressure was measured in a controlled environment after five minutes of rest in the sitting position on the right arm supported at heart level and was taken for three times ${ }^{35-37}$. Collected water sources were analyzed by DPHE, Water Testing Laboratory.

\section{RESULTS}

Among 528 participants most of them were male (353, $66.9 \%$ ) with mean age of 14 years $(185,35.0 \%)$. Most of them were from class $8(185,35.0 \%)$. Baseline characteristics for 528 participants shown in Table 1.

Prevalence of paternal, maternal, paternal grandparents' and maternal grandparents' history of hypertension are enlisted in table 01. About $72.3 \%$ regularly took extra salt during meal and $43.9 \%$ took salt preserved fish with meal (Table 01).

Table 1: Socio-demographic characteristics of respondents

\begin{tabular}{|l|c|}
\hline Traits & Coastal area (\%) \\
\hline Gender & 66.9 \\
\hline Male & 33.1 \\
\hline Female & \\
\hline Age & 35.0 \\
\hline 14 & 34.5 \\
\hline 15 & 30.5 \\
\hline 16 & \\
\hline Religion & 27.8 \\
\hline Muslim & 68.9 \\
\hline Hindu & 3.2 \\
\hline Christian & \\
\hline Level of education & 35.0 \\
\hline Class 8 & 35.5 \\
\hline Class 9 & \\
\hline
\end{tabular}


Salinity in drinking water and blood pressure

\begin{tabular}{|c|c|}
\hline Class 10 & 30.5 \\
\hline \multicolumn{2}{|l|}{ Familial history of hypertension } \\
\hline Family history & 82.0 \\
\hline Father & 32.4 \\
\hline Mother & 30.3 \\
\hline Paternal Grandfather & 14.0 \\
\hline Paternal Grandmother & 13.6 \\
\hline Maternal Grandfather & 10.0 \\
\hline Maternal Grandmother & 15.5 \\
\hline \multicolumn{2}{|l|}{ Behaviour Characteristics } \\
\hline Consumption of extra table salt with meal & 72.3 \\
\hline Consumption of extra salt from food & 83.1 \\
\hline Consumption of salt preserved fish & 43.9 \\
\hline \multicolumn{2}{|l|}{ Source of drinking water } \\
\hline Deep tube well & 21.5 \\
\hline Pond & 61.0 \\
\hline Rain water & 17.8 \\
\hline \multicolumn{2}{|l|}{ Source of cooking water } \\
\hline Deep tube well & 19.3 \\
\hline Pond & 75.6 \\
\hline Rain water & 5.1 \\
\hline
\end{tabular}

Mean of systolic blood pressure of respondents were $114.2197 \pm 7.61448 \mathrm{~mm}$ of $\mathrm{Hg}$. Mean of diastolic blood pressure of respondents were $75.1780 \pm 5.45959$ $\mathrm{mm}$ of $\mathrm{Hg}$. Mean of pulse pressure of respondents were $39.0417 \pm 6.56430$. Mean of mean arterial pressure of respondents were $88.1919 \pm 5.44267 \mathrm{~mm}$ of $\mathrm{Hg}$ (Table 02). Means of four types of blood pressure were calculated after adjustment for the effect of age, family history of high blood pressure, extra salt and salted fish intake.
The sodium measurements showed high sodium concentrations in several drinking water sources including some of the tube well sources, however, with large variation within each type of source (Table 3). Sodium concentrations of pond were approximately in between $500-600 \mathrm{mg} / \mathrm{l}$, whereas in tube wells approximately in between $700-1100 \mathrm{mg} / 1$ (Table 3).

Table 2: Blood pressure of the respondents (mean \pm SD)

\begin{tabular}{|c|c|}
\hline Blood Pressure & Coastal area (\%) \\
\hline SBP & $114.2197 \pm 7.61448$ \\
\hline DBP & $75.1780 \pm 5.45959$ \\
\hline PP & $39.0417 \pm 6.56430$ \\
\hline MAP & $88.1919 \pm 5.44267$ \\
\hline
\end{tabular}

$\mathbf{S B P}=$ Systolic Blood Pressure, $\mathbf{D B P}=$ Diastolic Blood Pressure, $\mathbf{P P}=$ Pulse Pressure, $\mathbf{M A P}=$ Mean Arterial Pressure 
Salinity in drinking water and blood pressure

Table 3: Distribution of the respondents according to Na Level by Water Source

\begin{tabular}{|c|c|c|c|c|c|}
\hline District & \multirow{2}{*}{ Upazila } & Mouza & School Name & Water Source Type & $\begin{array}{c}\text { Na } \\
(\mathbf{m g} / \mathbf{l})\end{array}$ \\
\hline \multirow{3}{*}{ Khulna } & \multirow{3}{*}{ Dacope } & Bajua 19 No. & Bajua High School & Pond & 500 \\
\cline { 3 - 6 } & Bajua 19 No. & West Bajua High School & Pond & 600 \\
\cline { 3 - 6 } & Chunkuri* & Nill & Shallow Tube Well & 1100 \\
\cline { 3 - 6 } & & Chunkuri** & Chunkuri High School & Shallow Tube Well & 700 \\
\hline
\end{tabular}

\section{DISCUSSION}

Regarding sodium concentration, the current study revealed that sodium concentration in ponds, tube wells systems are extremely high and found a significant association between sodium level in drinking water and blood pressure. The results are similar with previous study related to dietary sodium reduction, though the effect of sodium found in water is somewhat higher than has been reported for food containing sodium ${ }^{27,37-39}$. This might be partly explained by the way imbibed sodium is absorbed in the body compared to sodium consumed through food $^{40}$. Other studies ${ }^{41,42}$ have found reversibility of blood pressure changes through manipulation of sodium in drinking water and found similar results.

This study was a cross-sectional study conducted on adolescent to assess their blood pressure status and sodium level of drinking water. Although in several other studies on sodium level in drinking water were carried out in the last 3 decades of the 20th century mainly analyzing the salinizing effect of certain water softeners ${ }^{25,43-45}$. The high drinking water sodium concentrations described here are of particular importance, as they affect millions of people living in poor coastal areas, in which often no or very limited alternative sources are available for consumption.

This study was done in coastal area of Bangladesh, findings may be more widely generalizable to other deltaic areas in South-East Asia ${ }^{46,47}$. An increase of 1.9 $\mathrm{g}$ of dietary salt per day is associated with a $32 \%$ increase of stroke risk ${ }^{48-50}$. A systematic review indicated that reduction of dietary sodium intake below $2 \mathrm{~g} / \mathrm{d}$ would lead to a fall in systolic/diastolic blood pressure of $3.47 / 1.81 \mathrm{mmHg}$, associated with a $19 \%$ reduction in stroke risk, a $39 \%$ decrease in stroke mortality and a $42 \%$ decrease in coronary heart disease mortality ${ }^{26}$. This study found a strong effect on blood pressure for sodium consumed through water than through food, this may translate into a larger sodiumrelated morbidity and mortality in coastal areas of Bangladesh.

\section{CONCLUSION}

Sodium in drinking water is an important source of daily sodium intake and therefore it is a risk factor for increased BP in salinity prone coastal areas. This adds to the cardiovascular health risks associated with sodium intake in foodstuff in Southeast Asian populations. Water sources with low salinity could effectively help to prevent high BP and hypertensionrelated morbidity and mortality in coastal populations. New technologies and advancement for the supply of such alternative sources, ensuring the microbial quality, should be further studied.

\section{ETHICAL APPROVAL}

The objectives and importance of the research were explained to all participants prior to recruitment. Participation in the study was voluntary. The confidentiality of the participants was maintained, and written informed consent was obtained from all. The study was approved by the Institutional Review Board (IRB) of the National Institute of Preventive and Social Medicine (NIPSOM) and obtained an ethical clearance waiver from same source.

\section{DECLARATION}

No funding facilities were available for this study and all authors have read and approved the final version of the manuscript and also none of the participating authors has a conflicting financial or other interest related to the work detailed in this manuscript.

\section{ACKNOWLEDGEMENTS}

We thank all the participants for their voluntary participation for the study. We also thank to all of the honorable headmasters of our respondent's school for giving data collection permission and also the Upazilla Parishad chairman for permitting us to collect water from different sources of study please for research purpose. 


\section{REFERENCES}

1. Gupta R.K. et al. (2008) Soil salinity and salinization. In: Chesworth W. (eds) Encyclopedia of Soil Science. Encyclopedia of Earth Sciences Series. Springer, Dordrecht. https://doi.org/10.1007/978-1-4020-3995-9_552

2. Sposito, G., and Mattigod, S.V., 1977. On the chemical foundation of the sodium adsorption ratio. Soil Sci. Soc. Am. J., 41: 323-329.

3. Oster, J.D., and Frenkel, H., 1980. The chemistry of the reclamation of sodic soils with gypsum and lime. Soil Sci. Soc. Am. J., 44: 41-45.

4. Sverdrup H, Johnson M, Fleming R. Chemistry of Sea Water. Ocean Their Physics, Chem Gen Biol [Internet]. 1942;165-227.

Available from:

http://scholar.google.com/scholar?hl=en\&btnG= Search\&q=intitle: $19+42 .+$ The + oceans: + their + ph ysics, + chemistry+and + general+biology $\# 0$

5. WHO, Chlorides in drinking water. Br Med J. 1898;1(1938):520-1.

6. WHO, Nutients in Drinking Water. Page: 210, 2005

Available at:

https://www.who.int/water_sanitation_health/pu blications/nutrients-in-dw/en/

7. WHO, Hardness in drinking-water : background document for development of WHO guidelines for drinking-water quality.

Available at:

https://apps.who.int/iris/handle/10665/70168

8. WHO, Chemical Hazards in Drinking Water: Hardness.

Available at:

https://www.who.int/water_sanitation_health/wat er-quality/guidelines/chemicals/hardness/en/

9. Mcmichael, AJ 2003 Climate change and human health: risks and responses. World Health Organization.

10. Talukder, MRR, Rutherford, S, Phung, D, Islam, $\mathrm{MZ}$ and Chu, C 2016 The effect of drinking water salinity on blood pressure in young adults of coastal Bangladesh. Environmental Pollution 214: 248-254. DOI:

10.1016/j.envpol.2016.03.074
11. Kishore, J, Gupta, N, Kohli, C and Kumar, N 2016 Prevalence of hypertension and determination of its risk factors in rural Delhi. International journal of hypertension , 2016. DOI: $10.1155 / 2016 / 7962595$

12. Khan, AE, Scheelbeek, PFD, Shilpi, AB, Chan, Q, Mojumder, SK, Rahman, A, Haines, A and Vineis, P 2014 Salinity in drinking water and the risk of (pre) eclampsia and gestational hypertension in coastal Bangladesh: A casecontrol study. PLoS One 9: e108715. DOI: 10.1371/journal.pone.0108715

13. Jindal, R, Jindal, N and Dass, A 2016 Prevalence of hypertension and its association with various risk factorsa survey in Uttar Pradesh. International Journal of Contemporary Medical Research 3: 3410-3412.

14. Ibrahim, MM and Damasceno, A 2012 Hypertension in developing countries. The Lancet 380: 611-619. DOI: 10.1016/S01406736(12)60861-7

15. Vineis, $P$, Chan, $Q$ and Khan, A 2011 Climate change impacts on water salinity and health. Journal of Epidemiology and Global Health 1: 5-10. DOI: 10.1016/j.jegh.2011.09.001

16. Ahmad H (2019) Bangladesh Coastal Zone Management Status and Future. J Coast Zone Manag 22:1.

17. Hugh Brammer, Bangladesh's dynamic coastal regions and sea-level rise, Climate Risk Management, Volume 1, 2014, Pages 51-62, ISSN 2212-0963,

https://doi.org/10.1016/j.crm.2013.10.001

18. Minar MH, Hossain MB, Shamsuddin MD. Climate change and coastal zone of Bangladesh: Vulnerability, resilience and adaptability. Middle East J Sci Res. 2013;13(1):114-20.

19. M.A. Allison, S.R. Khan, S.L. Goodbred, S.A. Kuehl, Stratigraphic evolution of the late Holocene Ganges-Brahmaputra lower delta plain Sed. Geol., 155 (2003), pp. 317-342

20. H. Brammer, The Physical Geography of Bangladesh, University Press Ltd, Dhaka (2012)

21. Sarker, M.H., Choudhury, G.I., Akter, J., Hore, S.K., 2013. Bengal Delta Not Subsiding at a Very High Rate.

22. Vidal, J., 2013a. Sea change: the Bay of Bengal's vanishing islands, The Guardian. 
23. Khan AE, Ireson A, Kovats $\mathrm{S}$, et al. Drinking water salinity and maternal health in coastal Bangladesh: implications of climate change. Environ Health Perspect 2011;7.

24. Seal L, Baten MA. 2012. Salinity Intrusion in Interior Coast: A New Challenge to Agriculture in South Central part of Bangladesh Journal of Epidemiology and Global Health (2011) 1, 5- 10

25. Calabrese, E., \& Tuthill, R. (1985).The Massachusetts blood pressure study, part3.Toxicology and Industrial Health, 1(1), 19-34.

26. Aburto NJ, Ziolkovska A, Hooper L, Elliott P, Cappuccio FP, Meerpohl JJ. 2013. Effect of lower sodium intake on health: Systematic review and meta-analyses. BMJ346:f1326, PMID: 23558163, doi:10.1136/bmj.f1326.

27. Elliott P, Stamler J, Nichols R, Dyer AR, Stamler R, Kesteloot H, et al.1996. Intersalt revisited: Further analyses of 24 hour sodium excretion and blood pressure within and across populations. doi:10.1136/bmj.312.7041.1249.

28. Elliott P, Walker LL, Little MP, Blair-West JR, Shade RE, Lee DR, et al.2007. Change in salt intake affects blood pressure of chimpanzees implications for human populations. Circulation 116:1563-1568, doi:10.1161/CIRCULATIONAHA.106.675579.

29. Elliott P, Stamler J. 2002. Commentary: Evidence on salt and blood pressure is consistent and persuasive. Int J Epidemiol31:316-319, PMID: 11980788, doi:10.1093/ije/31.2.316.

30. Pietinen P, Uusitalo U, Nissinen A, Group ICR. 1988. Intersalt: An international study of electrolyte excretion and blood pressure. Results for 24 hour urinary sodium and potassium excretion. BMJ297:319-328, PMID: 3416162, doi:10.1136/bmj.297.6644.319.

31. Calabrese EJ, Tuthill RW. The influence of elevated levels of sodium in drinking water on elementary and high school students in Massachusetts. Sci Total Environ 1981;18:11733.

32. Robert W. Tuthill, Phd, And Edward J. Calabrese, Phd. 1981. Drinking Water Sodium and Blood Pressure in Children:A Second Look Am J Public Health. 71:722-729.

33. Bangladesh Bureau of Statistics, Bangladesh National Drinking Water Quality Survey of 2009.

Available at: https://washdata.org/sites/default/files/document s/reports/2019-06/Bangladesh-2009-MICSwater-quality-report.pdf

34. Akter, T., Jhohura, F.T., Akter, F. et al. Water Quality Index for measuring drinking water quality in rural Bangladesh: a cross-sectional study. J Health Popul Nutr 35, 4 (2016). https://doi.org/10.1186/s41043-016-0041-5

35. Zamorski MA, Green LA. NHBPEP report on high blood pressure in pregnancy: a summary for family physicians [published correction appears in Am Fam Physician 2002 Feb 15;65(4):560]. Am Fam Physician. 2001;64(2):263-216.

36. US Preventive Services Task Force Guides to Clinical Preventive Services. Rockville (MD): Agency for Healthcare Research and Quality (US); 1996-. Available from:

https:/www.ncbi.nlm.nih.gov/books/NBK61778

37. The Guide to Clinical Preventive Services 2012: Recommendations of the U.S. Preventive Services Task Force. Rockville (MD): Agency for Healthcare Research and Quality (US); 2012 Oct. Preventive Services Recommended by the USPSTF. Available from:

https:/www.ncbi.nlm.nih.gov/books/NBK11511 3/

38. He FJ, Li J, Macgregor GA. 2013. Effect of longer-term modest salt reduction on blood pressure. Cochrane Database Syst Rev 4:CD004937.

39. Sacks FM, Svetkey LP, Vollmer WM, Appel LJ, Bray GA, Harsha D, et al. 2001. Effects on blood pressure of reduced dietary sodium and the dietary approaches to stop hypertension 514 (DASH) diet. New England journal of medicine 344:3-10.

40. Pietinen P, Uusitalo U, Nissinen A, Group ICR. 1988. Intersalt: An international study of electrolyte excretion and blood pressure. Results for 24-hour urinary sodium and potassium excretion.

41. Lifshitz F, Wapnir RA. 1985. Oral hydration solutions: Experimental optimization of water 492 and sodium absorption. The Journal of Pediatrics 106:383-389.

42. Lenel R, Katz L, Rodbard S. 1948. Arterial hypertension in the chicken. American Journal of 490 Physiology--Legacy Content 152:557-562.

43. Sapirstein LA, Brandt WL, Drury DR. 1950. Production of hypertension in the rat by 
substituting hypertonic sodium chloride solutions for drinking water. Experimental Biology and Medicine 73:82-85.

44. Calabrese EJ, Tuthill RW. 1985. The massachusetts blood pressure study, part 3. Experimental reduction of sodium in drinking water: Effects on blood pressure. Toxicol Ind Health 1:19-34.

45. Hofman A, Valkenburg HA, Vaandrager GJ. 1980. Increased blood pressure in schoolchildren related to high sodium levels in drinking water. J Epidemiol Community Health 34:179-181.

46. Luft FC, Zemel MB, Sowers JA, Fineberg NS, Weinberger MH. 1990. Sodium bicarbonate 494 and sodium chloride: Effects on blood pressure and electrolyte homeostasis in normal and 495 hypertensive man. Journal of hypertension 8:663-670.

47. Hoque M, Scheelbeek P, Vineis P, Khan A, Ahmed K, Butler A. 2016. Drinking water vulnerability to climate change and alternatives for adaptation in coastal south and south east asia. Climatic Change 136:247-263. 471

48. Hoque MA, Butler AP. 2015. Medical hydrogeology of asian deltas: Status of groundwater toxicants and nutrients, and implications for human health. International journal of environmental research and public health 13:81.

49. Cook NR, Cutler JA, Obarzanek E, Buring JE, Rexrode KM, Kumanyika SK, et al. 2007. Long term effects of dietary sodium reduction on cardiovascular disease outcomes: Observational follow-up of the trials of hypertension prevention (TOHP). BMJ 334:885.

50. Cook NR, Appel LJ, Whelton PK. 2014. Lower levels of sodium intake and reduced cardiovascular risk. Circulation 129:981-989. 